\title{
Carbon Sequestration Potential through Agroforestry: A Review
}

\section{Raj Kumar Gupta ${ }^{1 *}$, Vijay Kumar ${ }^{2}$, K.R. Sharma ${ }^{3}$, Tejbir Singh Buttar ${ }^{3}$, Gobinder Singh ${ }^{3}$ and Gowhar Mir ${ }^{1}$}

${ }^{1}$ Division of Agroforestry, ${ }^{2}$ Rainfed Research Sub-station for Sub-tropical fruits, Raya, ${ }^{3}$ Division of Soil Science and Agricultural Chemistry, Sher-e- Kashmir University of Agricultural Sciences and Technology, Jammu - 180 009, (J\&K), India

*Corresponding author

\section{A B S T R A C T}

Carbon sequestration is basically the progression of transforming carbon in the air (carbon dioxide or $\mathrm{CO}_{2}$ ) stored in the soil carbon. Carbon dioxide is taken up with plants through the process of photosynthesis and built-in into living plant material. Agroforestry provides

Keywords

Agroforestry, Carbon sequestration, Soil carbon

Article Info

Accepted:

04 June 2017

Available Online:

10 August 2017 a sole opportunity to combine the double objectives of climate change adaptation and mitigation. It is an attractive alternative for sequestering carbon on agroforestry lands since it can sequester chief amounts of carbon still as leaving the bulk of the land in the production. It is most important option for carbon storage potential in its manifold plant species and soil, high applicability and indirect effects such as decreasing pressure on natural forest or soil erosion. The tree components in agroforestry systems can be important sinks of atmospheric carbon due to their fast growth and high productivity. It has the ability to enhance the flexibility of the system for coping with the unfavourable impacts of climate change. These systems suggest important opportunities for creating synergies between both adaptation and mitigation behaviour. Thus, although agroforestry systems seem to have high potential for $\mathrm{C}$ sequestration, significant effort is essential in realistically assessing the extent of this potential. The responsibility of agroforestry practices in climate change mitigation and adaptation is required to realize the potential next to overcoming various components of current and future international climate mitigation policies.

\section{Introduction}

Carbon (C) is found in all living organisms and is the main building block for life on earth. It is present in the soil organic matter, plants and animals, geologic deposits, atmosphere as carbon dioxide $\left(\mathrm{CO}_{2}\right)$ and dissolved in sea water. There is a growing interest in the role of diverse types of land use systems in stabilizing the atmospheric $\mathrm{CO}_{2}$ concentration and reducing the $\mathrm{CO}_{2}$ emissions or on increasing the carbon sink of agroforestry systems. Agroforestry has been recognized as a means to reduce $\mathrm{CO}_{2}$ emissions as well as enhancing carbon sinks. Although the pristine natural ecosystems represent the largest vegetation and soil $\mathrm{C}$ sinks, a considerable extent of this has already been lost especially in the less developed and developing countries of the world. It is unlikely that these degraded and deforested sites will be returned to natural forest cover. The need for transforming some of the lower biomass land uses (such as arable croplands 
and fallows) to carbon-rich tree based systems such as plantation forests and agroforestry therefore assumes significance. Agroforestry systems (AFS) spread over one billion ha in diverse eco-regions around the world have a special relevance in this respect. These woody perennial based land use systems have relatively high capacities for capturing and storing atmospheric $\mathrm{CO}_{2}$ in vegetation, soils and biomass products.

Management of agricultural systems to sequester $\mathrm{C}$ has been received as a partial solution to climate change (Morgan et al., 2010). Establishing and maintaining perennial vegetation to enhance $C$ sequestration is less costly compared to most other techniques, and these practices have minimal environmental and health risks. Perennial vegetation is more efficient than annual vegetation as it allocates a higher percentage of $\mathrm{C}$ to below-ground and often extends the growing season (Morgan et al., 2010), so enhancing $\mathrm{C}$ sequestration potential of agricultural systems even further (Oelbermann et al., 2006; Jose, 2009).

Agroforestry for carbon sequestration is attractive because (Makundi and Sathaye, 2004): (a) it sequesters carbon in vegetation and in soils depending on the pre-conversion soil C, (b) the more intensive use of the land for agricultural fabrication reduces the need for slash-and-burn or shifting cultivation, (c) the wood products produced under agroforestry serve as alternative for similar products unsustainably harvested from the natural forest, (d) to the extent that agroforestry increases the income of farmers, it reduces the incentive for further extraction from the natural forest for income augmentation, and finally, (e) agroforestry practices may have dual mitigation benefits as fodder species with high nutritive value can help to intensify diets of methane-producing ruminants while they can also sequester carbon (Thornton and Herrero, 2010).
Agroforestry provides a unique opportunity to combine the twin objectives of climate change adaptation and mitigation strategies. Although agroforestry systems are not primarily designed for carbon sequestration, there are many recent studies that substantiate the evidence that agroforestry systems be capable of play a major role in storing carbon in aboveground biomass (Mutuo et al., 2005; Verchot et al., 2007) and in soil (Nair et al., 2009) and in belowground biomass (Nair et al., 2009). Agro-forestry have carbon storage potential in its numerous plant species and soil, high applicability in agricultural land, and indirect effects such as decreasing pressure on natural forest or soil erosion (Montagnini and Nair, 2004). The utilization of the environment by species includes three main components: space, resources, and time. Any species utilizing the same exact combination of these resources as another will be in direct competition which could lead to a reduction in $\mathrm{C}$ sequestration.

The tree components in agroforestry systems can be important sinks of atmospheric carbon due to their fast growth and high productivity. Thus, promoting agroforestry can be one of the options to deal with problems related to land use and $\mathrm{CO}_{2}$ induced global warming. The amount of carbon sequestered motivation largely depends on the agroforestry system, its structure and function which to a great extent, are determined by environmental and socio-economic factors. Also tree species and system management can influence carbon storage in agroforestry systems (Albrecht and Kandji, 2003). In this paper, we present a review of carbon sequestration potential of agroforestry systems, this necessitate for more studies estimating the potential of agroforestry systems, specify the multiple benefits of these systems and the potential to provide synergy between climate change mitigation and adaptation by way of decreasing the susceptibility of communities 
to climate risks and climate change in the long period.

\section{Benefits of agroforestry systems}

Agroforestry has the potential to offer both economic and environmental reimbursement (Schoeneberger, 2009). Some of the major benefits of maintaining agroforestry systems are discussed below.

\section{Enhanced soil fertility}

Soil fertility is good-looking and maintaining for vital in the food security, falling poverty, preserving environment and for sustainability (Pandey, 2007). Agroforestry land use systems like agro-horticulture, agro-pastoral system, agri-silvipastoral system, etc., are proficient ways of restoring soil organic matter (Pandey, 2007). Jama et al., (2006) reported that yield is higher with improved crop rotation than with continuous cropping. The leaf litter from agroforestry practices, forms humus after decomposition and improves various soil properties (ICAR, 2006). Agroforestry systems can also control runoff and soil erosion, thereby dipping losses of water and nutrients, soil material and organic matter. It can make sure development of soil toxicities, both soil acidification and salinization and trees can be employed in the reclamation of polluted soils.

\section{Improved income}

The varied component of agroforestry provides multiple harvests at different times of the year. It increases food production, improves supply of fodder for fish and livestock, increases supply of fuel wood, improves soil fertility and water supply, habitats, etc. Therefore it reduces the risk of crop failure and ensures alternate income for the farmers (Pandey, 2007).

\section{Augmented carbon stock}

Agroforestry has a huge potential as mitigation strategy to the changing climate because of its potential to sequester carbon in its several plant species and soil (Albrecht and Kandji, 2003; ICAR, 2006). The normal carbon sequestered by these practices has been estimated to be $9,21,50$, and $63 \mathrm{Mg} \mathrm{C}$ ha $^{-1}$ in semiarid, sub-humid, humid, and temperate regions. In the tropics, for small agroforestry systems, it has been found to be ranging from 1.5 to $3.5 \mathrm{Mg} \mathrm{C}^{-1} \mathrm{yr}^{-1}$ and as a consequence can be a viable strategy for carbon storage (Roshetko et al., 2007; Montagnini and Nair, 2004). In degraded soils of the subhumid tropics, agroforestry practices have been establish to increase top soil carbon stocks up to $1.6 \mathrm{Mg} \mathrm{C} \mathrm{ha}^{-1} \mathrm{yr}^{-1}$ (Mutuo et al., 2005). Hence, proper designing and managing of agro forests can make them successful carbon sinks.

\section{Decreased vulnerability}

Agroforestry improves the resilience of farming systems besides buffering against different risks, both biophysically (hydraulic lift, soil fertility) and financially by diversification and income risk (Verchot et al., 2007). On the other hand the advantage for include dropping seasonal labour peaks, earn income throughout the year and ensure remuneration over the small, middle and lengthy term (FAO, 2005).

\section{Improved productivity}

Agroforestry systems have influenced soils give superior yields than ordinary soils. Taungya cultivators got higher yields than from pure agriculture in Tarai region of Uttar Pradesh. IGFRI, Jhansi conducted experiments that indicated increased yield of fodder when fodder grasses were intercropped with fodder trees as compared to mono 
cropping of fodder grass. In South India, and states like Punjab, Haryana, Uttar Pradesh and Gujarat, intercropping agroforestry food crops was found to be more productive (Prasad, 2003).

\section{Aesthetic worth}

Agroforestry practices can enhance the soil, water, air, animal and human being resources in the country. It was may use only $5 \%$ of the farming land area, yet account for over 50 percent of the biodiversity, improving wildlife habitat and harbouring birds and beneficial insects which feed on crop pests. Tree biodiversity adds variety to the landscape and improves aesthetics values. Other advantages include-utilization of solar energy more efficiently than monocultural systems, reduced insect pests and associated diseases, increased nitrogen inputs because of nitrogen fixing trees and shrubs. It was also moderate microclimates and shelter given by trees improves yields of nearby crops and livestock.

Measurement of carbon sequestration in agroforestry systems

\section{Aboveground (Vegetation)}

Aboveground measurements of $\mathrm{C}$ stock (implication, $\mathrm{C}$ sequestration) are direct derivatives of aboveground biomass (AGB) measurements/estimates, assuming that $50 \%$ of the biomass is made. The AGB is often derived by summing up the amount of harvested and standing biomass, and the measurements are relatively straight-forward compared to those of the belowground section. Estimation of tree biomass by wholetree harvesting is an old approach: it consists of cutting down sample trees, separating various parts (stem, leaves, inflorescence, etc.), digging out and washing the roots, determining their dry weights from each part, and adding them up to get the total biomass. After dividing up the harvested representative trees into their several components (branches, dead branches, branchlets, leaves, roots and fine roots), and determining their dry weight, the $\mathrm{C}$ content in each is measured. Using the data, allometric equations are developed as regression models with the measured variables such as diameter at breast height $(\mathrm{DBH})$, total tree height or commercial bole height, and sometimes wood density, as the independent variables and total dry weight as the dependent variable.

The destructive technique of determining tree biomass, though comparatively accurate, is tremendously time and labour intensive, especially for large trees. It is often use to validate other, fewer invasive and costly methods, such as the estimation of $\mathrm{C}$ stock using non-destructive in-situ measurements and remote sensing. In the allometric equations developed based on bio-physical properties of trees and validated by occasional measurements of destructive sampling are widely used in forestry for estimating standing volumes of forests. With increasing understanding about the role of forests in sequestering $\mathrm{C}$, diverse allometric equations have been developed for different forest types (Basuki et al., 2009 and Fernandez-Nunez et al., 2010).

\section{Belowground (Soils)}

The determination of belowground organic $\mathrm{C}$ dynamics in AFS is critical for understanding the impact of the system on $\mathrm{C}$ sequestration, but it is difficult than that for aboveground $\mathrm{C}$. Organic $\mathrm{C}$ occurs in soils in a number of different forms including living root and hyphal biomass, microbial biomass, and as soil organic matter (SOM) in labile and more recalcitrant forms. Complications of separating these different forms and their complex interactions make measurement, 
estimation and prediction of soil C sequestration a daunting task. The most common method of estimating the amount of $\mathrm{C}$ sequestered in soils is based on soil analysis, whereby the $\mathrm{C}$ content in a sample of soil is determined (mass per unit mass of soil, such as g C per $100 \mathrm{~g}$ soil) and expressed usually in mega grams $\left(\mathrm{Mg}=10^{6} \mathrm{~g}\right.$ or tons) per hectare. Soil organic C (SOC) is often measured on a whole soil basis. The WalkleyBlack method that used to be employed extensively in the past, and is perhaps used even now in some places, is no longer recommended because of concerns about the accuracy of determination. Currently, several studies measure SOC by quantifying the amount of $\mathrm{CO}_{2}$ produced through heating in a furnace. Other studies measure the change in weight of the sample after heating. However, the temperature used can differ; it needs to be standardized for accurate comparison of different studies. The existence of carbonates and charcoal in the soil can also skew results (Kimble et al., 2001). These measurements of $\mathrm{C}$ on a whole soil basis provide information about total concentrations, but other analytical procedures are needed to determine details of the form and recalcitrance of the stored $\mathrm{C}$ as well as where it is stored. In order to gain a better understanding of such details of $\mathrm{C}$ sequestration in soils, attention has focused on the study of soil aggregates (Nair et al., 2010).

\section{Belowground living biomass}

The root-to-shoot ratio is therefore commonly used to estimate below ground living biomass. The ratios fluctuate considerably among species (e.g., higher in palms than in dicot trees) and across ecological regions (e.g., higher in cold than in warm climates). In adding up to SOM, belowground biomass is a major C pool (Nadelhoffer and Raich, 1992). The absence of measured values, various researchers assume that the belowground biomass constitutes a defined portion of the aboveground biomass and the values so assumed range from $25 \%$ to $40 \%$ depending on such factors as nature of the plant and its root system and ecological conditions.

\section{Major agroforestry practices followed in India}

In the shifting cultivation, home gardens and plantation-based cropping systems are mostly practiced in humid tropical regions. In India, home gardens are found in Kerala and Andaman and Nicobar Islands. Taungya, boundary plantations, live hedges, range land trees are agro ecologically adapted to all regions. Boundary plantations are found in Uttar Pradesh, Gujarat, in parts of south India, particularly the Nilgiri hills, Haryana, Himachal Pradesh, Bihar and Orissa. Woodlots are found in hilly areas whereas shelter belts are found in wind-prone regions like coastal areas. In India, woodlots are found in Andhra Pradesh, Tamil Nadu, Karnataka, Orissa, Punjab, Haryana, Gujarat and Assam. Scattered trees on farmlands are found in all regions specially arid and semiarid. Agro-silvo-pastoral practices are found in semiarid regions of India (Puri and Nair, 2004).

\section{Carbon sequestration in different agroforestry systems}

Agroforestry is an attractive and promising option for carbon sequestration on agricultural lands because it can sequester significant amounts of carbon while leaving the bulk of the land for agricultural production (Montagnini and Nair, 2004). The tree components in agroforestry systems can be significant sinks of atmospheric $\mathrm{C}$ due to their fast growth and high productivity. 
Table.1 Major Agroforestry practices followed in India

\begin{tabular}{|c|c|}
\hline Practices & Agroecological region / states \\
\hline Boundary planting and live hedges & In all regions \\
\hline Farm woodlots & Throughout the country \\
\hline Homegardens & $\begin{array}{l}\text { Mainly tropical west coast region, especially } \\
\text { Kerala, southern Karnataka, Andaman \& Nicobar } \\
\text { Islands }\end{array}$ \\
\hline Industrial plantations with crops & $\begin{array}{l}\text { Intensively cropped areas in northern and } \\
\text { northwestern regions: Haryana, Himachal Pradesh, } \\
\text { Punjab, Uttar Pradesh; also in southern states } \\
\text { (Andhra Pradesh, Karnataka, Kerala, and Tamil } \\
\text { Nadu) }\end{array}$ \\
\hline Scattered trees on farms, parklands & All regions, especially semiarid and arid regions \\
\hline $\begin{array}{l}\text { Shaded perennial systems with } \\
\text { plantation crops }\end{array}$ & $\begin{array}{l}\text { Mainly humid tropical region in the southern } \\
\text { region; also Assam,W. Bengal }\end{array}$ \\
\hline Shelterbelts and windbreaks & $\begin{array}{l}\text { In wind-prone areas, esp. coastal, arid, and alpine } \\
\text { regions }\end{array}$ \\
\hline Silvopasture: & Throughout the country \\
\hline Fodder trees, & Subtropical and tropical; orchards in hilly regions \\
\hline $\begin{array}{l}\text { Intercropping/grasses with fruit trees } \\
\text { Seasonal forest grazing }\end{array}$ & Semiarid and mountainous ecosystem \\
\hline Taungya & Eastern region \\
\hline $\begin{array}{l}\text { Tree planting for reclamation of saline } \\
\text { soils and wastelands }\end{array}$ & $\begin{array}{l}\text { Semiarid and canal-irrigated regions, mostly in the } \\
\text { northern and northwestern Regions }\end{array}$ \\
\hline Woodlots for soil conservation & In hilly areas, along sea coast and ravine lands \\
\hline
\end{tabular}

Table.2 Carbon sequestration rates for selected agroforestry practices

\begin{tabular}{lcl}
\hline Agroforestry practice & Carbon sequestration rate $\left(\right.$ tones $\left.\mathrm{C} \mathrm{eq} \mathrm{ha}^{-1} \mathrm{yr}^{-1}\right)$ & \multicolumn{1}{c}{ Region } \\
\hline Complex agroforestry & 11 & Central Africa \\
Complex agroforestry & $8-21$ & Costa Rica \\
Boundary planting & $35-50$ & Central Africa \\
Hedgerow & $1-37$ & Indonesia and \\
intercropping & 145 & India \\
Home gardens & & Panama \\
\hline
\end{tabular}

Carbon sequestration rates are very hopeful for complex agroforestry, boundary planting, hedgerow intercropping and 'home gardens' (Calfapietra et al., 2010). Nevertheless, highest carbon storage grades are found in "multistory/complex" agroforestry systems (Sajwaj et al., 2008) that have various diverse species using ecological "niches" from the high canopy to bottom story shade tolerant crops (Table 2). The cash crops are grown under a canopy of trees that sequester carbon and provide habitats for wildlife. In fact, there is a need to develop agroforestry models as per differential value of tree crop species and also as per soil and climate differences.

Carbon sequestration in different agroforestry systems occurs both belowground, in the form of enhancement of soil carbon plus root biomass and aboveground as carbon stored in standing biomass. Some of the earliest studies of potential carbon storage in agroforestry 
systems and alternative land use systems for India had estimated a sequestration potential of $68-228 \mathrm{Mg} \mathrm{ha}^{-1}$ (Dixon et al., 1994). In different zone depending on the biomass production and magnitude of carbon sequestration from forestry activities would depend on the scale of operation and the final use of wood.

\section{Agri-silvicultural systems}

Agri-silvicultural systems involve the conscious and deliberate use of land for the concurrent production of agricultural crops including tree crops. These are many studies in the agri-silvicultural in India and aboard in carbon sequestration in tree biomass. The carbon sequestration probable of planted tree species on abandoned agricultural land (3.9 t/ $\left.\mathrm{ha}^{-1} \mathrm{yr}^{-1}\right)$ and degraded forest land (1.79 $\mathrm{t} \mathrm{ha}^{-1}$ $\left.\mathrm{yr}^{-1}\right)$. Soil carbon dynamics linking different pruning treatments were calculated in an agrisilvicultural system everywhere tree biomass was 23.61 to $34.49 \mathrm{t} \mathrm{ha}^{-1}$ with black grammustard. Chauhan et al., (2010) was reported that the poplar based agri-silvicultural system, total biomass in the system was $25.2 \mathrm{t} \mathrm{ha}^{-1}$ $113.6 \%$ higher than sole wheat cultivation, where net carbon storage was $34.61 \mathrm{t} \mathrm{ha}^{-1}$ compared to $18.74 \mathrm{t} \mathrm{ha}^{-1}$ in sole wheat cultivation. In a Poplar based agroforestry system, trees could sequester higher soil organic carbon buildup to $30 \mathrm{~cm}$ depth during the first year of plantation (6.07 $\left.\mathrm{t} \mathrm{ha}^{-1} \mathrm{yr}^{-1}\right)$ than in subsequent years (1.95-2.63 $\left.\mathrm{t} \mathrm{ha}^{-1} \mathrm{yr}^{-1}\right)$ with better soil carbon storage in sandy clays than loamy sand soils (Gupta et al., 2009).

\section{Silvopastrol systems}

The manufacture of woody plants mutual with pasture is referred to as silvipastoral system. The trees and shrubs may be used first and foremost to produce fodder for livestock or they may be grown for timber, fuelwood or fruit or to improve the soil. The silvipastoral system in a natural grassland in the semi-arid state of Uttar Pradesh, where introduced species of Albizia procera, Eucalyptus tereticornis, Albizia lebbeck, Embilica officinalis and Dalbergia sissoo accumulated $8.6,6.92,6.52,6.25$ and $5.41 \mathrm{t} / \mathrm{ha} / \mathrm{yr}$ of biomass (Rai et al., 2009). The carbon storage in the system was 1.89-3.45 $\mathrm{t} \mathrm{C} / \mathrm{ha}$ in silvipasture and $3.94 \mathrm{tC} / \mathrm{ha}$ in pure pasture. Kaur et al., (2002) observed that an increase in organic carbon of 1.7 to 2.3 times in a silvipastoral system connecting Leucaenea leucocephala, Cenchrus ciliaris and Stylosanthes hamata as compared to a control. Alike studies have observed that the higher organic carbon levels in dry sub-humid and arid ecosystems when grass species are intercropped with annual crops in a silvipastoral system with no increase in organic carbon with grasses in an arid ecosystem (Venkateswaralu, 2010). In a silvipastoral system, carbon flux in net primary productivity increased due to the integration of Prosopis juliflora and Dalbergia sissoo with grasses (Narain, 2008).

\section{Accumulation of carbon in homegardens}

Homegardens stand for land use systems involving management of multi-purpose trees and shrubs in intimate association with annual and perennial agricultural crops and, invariably, livestock, within the compounds of individual houses, the whole crop-treeanimal unit being intensively management by family labour. Kumar (2011) reported that aboveground standing stocks of $\mathrm{C}$ ranged from 16 to $36 \mathrm{Mg} \mathrm{ha}^{-1}$, where small homegardens often have higher $\mathrm{C}$ stocks on unit area basis compared to large- and mediumsized ones in tropical home-gardens of Kerala. The soil profile carbon for within $1 \mathrm{~m}$ $\mathrm{C}$ content ranged from 101.5 to $127.4 \mathrm{Mg} \mathrm{ha}^{-1}$ and the smaller sized home gardens less 0.4 ha with higher tree density and plant-species richness had (Saha et al., 2009) more soil C 
per unit area (119.3 $\left.\mathrm{Mg} \mathrm{ha}^{-1}\right)$ of land than larger-sized ones less 0.4 ha in $108.2 \mathrm{Mg} \mathrm{ha}^{-1}$.

\section{Accumulation of carbon in block and} boundary plantations

The carbon stock in the soil and above ground in the block and boundary plantation in the agroforestry systems may influence the soil fertility and build up carbon. These are several studies in India and aboard in carbon sequestration in tree biomass. Kumar,(2010) reported that the 9-year old block and boundary plantations for four different agroforestry systems (Populus deltoides block plantation + wheat, Eucalyptus hybrid boundary plantation + wheat, Populus deltoides boundary plantation + wheat and Populus deltoides block plantation + lemon grass), and it was found that total carbon sequestration in trees was $70.59,21.38$, 116.29 and $18.53 \mathrm{t} \mathrm{ha}^{-1}$ in system Populus deltoides + wheat followed by $68.53,20.63$, 113.03 and $17.60 \mathrm{t} \mathrm{ha}^{-1}$ in system Populus deltoides + Lemon grass, respectively.

In conclusion, Agroforestry systems that integrate tree production with crop and animal production systems are believed to have a higher potential to sequester $\mathrm{C}$ than pastures or field crops. This conjecture is based on the notion that tree incorporation in croplands and pastures would outcome in greater net aboveground as well as belowground $\mathrm{C}$ sequestration. It was promising practice to sequester $\mathrm{C}$ while providing numerous environmental, economical, and social benefits. Agroforestry could also protect existing $\mathrm{C}$ stocks if improved fallows and similar agroforestry practices could provide food and fuel wood, thereby reducing the rate of deforestation. Furthermore, agroforestry systems can contribute to reducing $\mathrm{CO}_{2}$ emissions by avoiding burning of forest-based fuel wood and conserving soil. Besides the potential of agroforestry systems to accumulate and sequester carbon, and these alternative for reducing deforestation rates in tropical and falling the vulnerability of farming system to climate variability and climate change impacts.

If the majority of the people are continuation farmers can receive even small amount of carbon payments through their agro-forestry practices, it would be a substantial contribution to their economic welfare and overall development of these region. With the introduction of carbon payments, agroforestry systems that are otherwise less profitable may become more attractive or vice-a-versa. Hence, the further research suggest that the addressing both biophysical and socioeconomic issues of carbon sequestration is essential.

\section{References}

Albrecht, A. and Kandji, S. T. 2003. Carbon sequestration in tropical agroforestry systems. Agriculture, Ecosystems and Environment, 99: 15-27.

Basuki, T. M., Van Laake, P. E., Skidmore, A. K. and Hussin Y. A. 2009. Allometric equations for estimating the above-ground biomass in tropical lowland dipterocarp forests. For. Ecol. Manag., 257: 1684-1694.

Caifapietra, C., Gielen, B., Karnosky, D., Ceulemans, R. and Mugnozza G. S. 2010. Response and potential of agroforestry crops under global change. Environ. Pollut, 158: 1095-1104.

Chauhan, S. K., Sharma, S. C., Beri, V., Yadav, S. and Gupta N. 2010. Yield and carbon sequestration potential of wheat (Triticum aestivum)-poplar (Populus deltoides) based agri-silvicultural system Indian. Journal of Agricultural Sciences, 80: 129- 35.

Dixon, R. K., Brown, S., Houghton, R. A., Solomon, A. M. and Trexler M. C. 
1994. Carbon pools and fluxes of global forest ecosystems. Science, 263: 185190

FAO. 2005. Realizing the economic benefits of agroforestry: experiences, lessons and challenges. In: State of the World's Forests 2005.

Fernandez-Nunez, E., Rigueiro-Rodriguez, A. and Mosquera-Losadaa M. R. 2010. Carbon allocation dynamics one decade after afforestation with Pinus radiata D. Don and Betula Alba L. under two stand densities in NW Spain. Ecol. Eng., 36:876-890.

Gupta, N., Kukal, S. S., Bawa, S. S. and Dhaliwal G. S. 2009. Soil organic carbon and aggregation under poplar based agroforestry system in relation to tree age and soil type. Agroforestry Systems, 76: 27-35.

ICAR. 2006. Handbook of Agriculture ( $5^{\text {th }}$ edn). Indian Council of Agricultural Research, New Delhi.

Jama, B., Kwesiga, F. and Niang A. 2006. Agroforestry innovations for soil fertility management in sub-Saharan Africa: Prospects and challenges ahead. World Agroforestry into the Future, 60 pp.

Jose, S. 2009. Agroforestry for ecosystem services and environmental benefits: an overview. Agroforestry Systems, 76: 110 .

Kaur, B., Gupta, S. R. and Singh G. 2002. Carbon storage and nitrogen cycling in silvipastoral system on sodic soil NorthWestern India. Agroforestry Systems, 54: 21-29.

Kimble, J. M., Lal, R. and Follett R. F. 2001. Methods for assessing soil $\mathrm{C}$ pools. In: Lal R., Kimble J. M., Follett R. F., Stewart B. A. (Eds.). Assessment methods for soil carbon. Lewis Publishers, Boca Raton, 3-12 pp.

Kumar, A. K. 2010. Carbon sequestration: underexplored environmental benefits of Tarai agroforestry. Indian Journal of Soil Conservation, 38: 125-131.

Kumar, B. M. 2011. Species richness and aboveground carbon stocks in the homegardens of central Kerala, India. Agriculture, Ecosystems \& Environment, 140(3-4): 430-440.

Makundi, W. R. and Sathaye J. A. 2004. GHG mitigation potential and cost in tropical forestry- relative role for agroforestry. Environment, Development and Sustainability, 6, 235260.

Montagnini, F. and Nair P. K. R. 2004. Carbon sequestration: An underexploited environmental benefit of agroforestry systems. Agroforestry Systems, 61: 281-295.

Morgan, J. A., Follett, R. F., Allen L. H., Grosso, S. D., Derner, J. D., Dijkstra, F., Franzluebbers, A., Fry, R., Paustian, K. and Schoeneberger, M. M. 2010. Carbon sequestration in agricultural land of the United States. J. Soil Water Conserv, 65: 6A-13A.

Mutuo, P. K., Cadisch, G., Albrecht, P. C. A. and Verchot, L. 2005. Potential of agroforestry for carbon sequestration and mitigation of greenhouse gas emissions from soils in the tropics. Nutrient Cycling in Agroecosystems, 71:43-54.

Nadelhoffer, K. J. and Raich J. W. 1992. Fine root production estimates and belowground carbon allocation in forest ecosystems. Ecology, 73:1139-1147.

Nair, P. K. R., Nair, V. D., Kumar, B. M and Haile, S. G. 2009. Soil carbon sequestration in tropical agroforestry systems: a feasibility appraisal. Environmental Science and Policy, 12: 1099-1111.

Nair, P. K. R., Nair, V. D., Kumar, B. M. and Showalter J. M. 2010. Carbon sequestration in agroforestry systems. Adv. Agron., 108: 237-307. 
Narain, P. 2008. Dryland management in arid ecosystem. Journal of the Indian Society of Soil Science, 56: 337-347.

Oelbermann, M., Voroney, R. P., Kass, D. C. L. and Schlonvoigt, A. M. 2006. Soil carbon and nitrogen dynamics using stable isotopes in 19- and 10-yr old tropical agroforestry systems. Geoderma, 130: 356-367.

Pandey, D. N. 2007. Multifunctional agroforestry systems in India. Current Science, 92: 455-463.

Prasad, K. 2003. Prospects of Agroforestry in India, XII. World Forestry Congress 2003.

Puri, S. and Nair P. K. R. 2004. Agroforestry research for development in India: 25 years of experiences of a national program. Agroforestry Systems, 61: 437-452.

Rai, P., Ajit, C. P. O., Singh, R. and Singh U. P. 2009. Biomass production in multipurpose tree species in natural grasslands under semi-arid conditions. Journal of Tropical forestry, 25: 11-16.

Roshetko, J. M., Lasco, R. D. and Angeles, M. S. D. 2007. Small holder agroforestry systems for carbon storage. Mitigation and Adaptation Strategies for Global Change, 12: 219-242.

Saha, S. K., Nair, P. K. R., Nair, V. D. and
Kumar, B. M. 2009. Soil carbon stock in relation to plant diversity of homegardens in Kerala, India. Agroforestry Systems, 76(1): 53-65.

Sajwaj, T., Harley, M. and Parker, C. 2008. Eliasch review: forest management impacts on ecosystem services. Report to the Office of Climate Change. EAT/ENVIR/2623/Issue 1:1-31.

Schoeneberger, M. M. 2009. Agroforestry: working trees for sequestering carbon on agricultural lands. Agroforestry Systems, 75: 27-37.

Thornton, P. K. and Herrero M. 2010. Potential for reduced methane and carbon dioxide emissions from livestock and pasture management in the tropics. Proceedings of the National Academy of Sciences of the United States of America, 107(46): 19667-19672.

Venkateswaralu, J. 2010. Rainfed agriculture in India: Research and development scenario. Indian council of Agricultural Research, New Delhi, 508 pp.

Verchot, L. V., Noordwijk, M. V., Kandji, S., Tomich, T. and Ong C. 2007. Climate change: linking adaptation and mitigation through agroforestry. Mitigation and Adaptation Strategies for Global Change, 12: 901-918.

\section{How to cite this article:}

Raj Kumar Gupta, Vijay Kumar, K.R. Sharma, Tejbir Singh Buttar, Gobinder Singh and Gowhar Mir. 2017. Carbon Sequestration Potential through Agroforestry: A Review. Int.J.Curr.Microbiol.App.Sci. 6(8): 211-220. doi: https://doi.org/10.20546/ijcmas.2017.608.029 